$\stackrel{\circ}{\text { II }}$

\title{
O INTEGRACJI \\ OPOZYCYJNYCH PARADYGMATÓW NAUK SPOŁECZNYCH. PRÓBA REWIZJI ZAŁOŻEŃ NIE-MARKSOWSKIEGO MATERIALIZMU HISTORYCZNEGO
}

\begin{abstract}
Mieszko Ciesielski, O integracji opozycyjnych paradygmatównauk społecznych. Próba rewizji założeń nie-Marksowskiego materializmu historycznego [Towards a theory integrating contradictory paradigms of social sciences. An attempt at a revision of premises of non-Marxian historical materialism], edited by K. Brzechczyn "Człowiek i Społeczeństwo" vol. XLII: Modelowanie świata społecznego. Założenia - rekonstrukcje - analizy [On Modeling of Social World: Assumptions - Reconstructions Analysis], Poznań 2016, pp. 73-91, Adam Mickiewicz University Press. ISSN 0239-3271.
\end{abstract}

The author embarks on the issue of integration of paradigms developed within social sciences. Usually, theoreticians distinguish three pairs of opposing paradigms: materialism/idealism, holism/ individualism, and antagonism/solidarism. The papers argues that Leszek Nowak's theory of nonMarxian historical materialism, after a revision of some of its underlying conceptual premises, might become a theory which overcomes one-sidedness of particular paradigms. The author's view is that modification of two premises, i.e. radical materialism, antagonistic notion of social being will make it possible to formulate a general social theory which integrates the paradigms in question. The article outlines the idea of a general social theory construed in this fashion.

Mieszko Ciesielski, Instytut Kultury Europejskiej UAM, ul. Kostrzewskiego 5-7, 62-200 Gniezno, Poland, e-mail: mieszko@amu.edu.pl

\section{Wstęp}

W naukach społecznych istnieją pewne ujęcia badawcze, paradygmaty ${ }^{1}$, opracowane na podstawie założeń ontologicznych i teoretycznych, jakie są w nich przyjmowane.

${ }^{1}$ W związku z wieloznacznością terminu „paradygmat” na potrzeby niniejszego tekstu przyjmuję, że „paradygmat nauk społecznych” to sposób ujęcia zjawisk społecznych 
Poszczególne teorie rozwoju społecznego można wyróżnić ze względu na:

- charakter czynników, jakie uznaje się za istotnie wpływające na kształt badanych zjawisk: ujęcie materialistyczne zasadniczej determinacji rozwoju społecznego upatruje w czynnikach natury materialnej, związanej z postępem technologicznym, materialnymi środkami społecznymi (środkami produkcji, przymusu, indoktrynacji) itp.; ujęcie idealistyczne, przeciwnie, wskazuje na czynniki związane z „duchem ludzkim”: świadomością społeczną, ideologią polityczną, przekonaniami religijnymi itp.;

- poziom rzeczywistości społecznej, jaki uznany jest za eksplanacyjnie podstawowy: ujęcie indywidualistyczne wskazuje na konieczność uwzględnienia w procesie poznawczym kategorii jednostkowych - osób i ich działań oraz wytworów tych działań; ujęcie holistyczne wykorzystuje język z kategoriami globalnymi: klasa społeczna, naród, kultura, cywilizacja itp.;

- rodzaj relacji społecznych, jaki uznaje się za zasadniczo determinujący ład społeczny: ujęcie antagonistyczne podkreśla doniosłą rolę w rozwoju społecznym konfliktów, walki, rywalizacji konkurencyjnej itp.; ujęcie solidarystyczne podkreśla zasadniczą rolę konsensusu społecznego, wspólnoty interesów, jedności ludzkiej itp.

Te trzy „osie kategorialne” wyznaczają charakterystykę paradygmatów: materializm/idealizm, holizm/indywidualizm, antagonizm/solidaryzm.

Od wielu lat badacze nauk społecznych postulują odejście od jednostronnych ujęć zjawisk społecznych, w których przyjmuje się radykalne „albo-albo”, na rzecz podejść integrujących: „i to, i to zarazem”. Wyrażę to w postaci postulatu integracji paradygmatów $(P I)$ :

PI: chcąc efektywnie poznawczo badać zjawiska społeczne, należy budować ujęcia konceptualne, które przezwyciężają opozycje dotychczasowych paradygmatów nauk społecznych.

Przykładowo, Anthony Giddens pisze o potrzebie przezwyciężenia opozycji holizm - indywidualizm - co można zinterpretować jako wyrażenie postulatu PI - i w swej teorii strukturacji przedstawia koncepcję integracji tych dwóch poziomów analizy społecznej:

O ile podstawą socjologii rozumiejącej jest jakby imperializm podmiotu, o tyle funkcjonalizm i strukturalizm, odwrotnie, bronią imperializmu przed-

(rozwoju społecznego itp.) na podstawie określonych założeń ontologicznych i teoretycznych. W szczególności chodzi tu o podział na ujęcia materialistyczne/idealistyczne, holistyczne/indywidualistyczne, antagonistyczne/solidarystyczne. 
miotu. Jednym z zasadniczych celów mojej teorii strukturacji jest położenie kresu obu rodzajom imperialistycznych ciągot ${ }^{2}$.

A zatem obok ujęć „,czystych”, mieszczących się wyłącznie po jednej stronie opozycji (czyli: albo materializm, albo idealizm; albo holizm, albo indywidualizm; albo antagonizm, albo solidaryzm), można zdefiniować ujęcia „mieszane”, które realizują postulat PI i próbują przezwyciężyć jednostronność paradygmatów nauk społecznych integrując je w pewien sposób ze sobą. Określę je jako ujęcia: materializm - idealistyczny, holizm - indywidualistyczny, antagonizm - solidarystyczny.

W związku z wyrażanym przez różnych badaczy postulatem integracji jednostronnych ujęć paradygmatycznych i tworzenia koncepcji unifikujących, chciałbym przyjrzeć się opracowanej przez Leszka Nowaka teorii społecznej nie-Marksowskiego materializmu historycznego (dalej: n-Mmh) pod kątem jej założeń ontologicznych i teoretycznych. Dwa cele będą przyświecać niniejszym rozważaniom: określenie, do jakiego paradygmatu nauk społecznych należy n-Mmh (z uwagi na przedstawione wyżej trzy pary opozycji), oraz wskazanie założeń przyjmowanych w n-Mmh, które poddane rewizji pozwoliłyby przeformułować tę teorię w koncepcję realizującą postulat PI, czyli integrującą poszczególne paradygmaty. O tym ostatnim pisał sam twórca teorii, który, stwierdziwszy pewne niedostatki n-Mmh, wyraził potrzebę przezwyciężenia ich w postaci „ogólnej teorii społecznej”:

Jaka ta postulowana teoria musiałaby być? Ani holistyczna [...], ani indywidualistyczna [...]. Ani antagonistyczna [...], ani solidarystyczna [...]. Ani czysto materialistyczna [...], ani czysto idealistyczna [...]. Czy teoria taka jest możliwa? Trudno powiedzieć. I nie będzie tego wiadomo tak długo, jak długo ktoś jej nie zrobi ${ }^{3}$.

Niniejsze rozważania można uznać za pierwszy krok na drodze do konceptualizacji wskazanej w powyższym cytacie teorii integrującej.

${ }^{2}$ A. Giddens, Stanowienie społeczeństwa. Zarys teorii strukturacji, Zysk i S-ka, Poznań 2003, s. 40.

${ }^{3}$ L. Nowak, Marksizm versus liberalizm: pewien paradoks, „Poznańskie Studia z Filozofii Humanistyki” t. 17: Marksizm, liberalizm, próby wyjścia, red. L. Nowak, P. Przybysz, Zysk i S-ka, Poznań 1997, s. 17. 


\section{Nie-Marksowski materializm historyczny. Zasadnicze idee i założenia}

Teoria rozwoju historycznego Leszka Nowaka stanowi istotną modyfikację i jest znaczącym rozwinięciem materializmu Marksowskiego ${ }^{4}$. W stosunku do materializmu historycznego Marksa rozwinięciu poddana została przede wszystkim koncepcja klas społecznych. Otóż, w teorii n-Mmh wyodrębnione są trzy sfery społeczeństwa: gospodarczy, polityczny i kulturowy.

${ }^{4}$ Systematyczny wykład teorii zawiera praca: L. Nowak, U podstaw teorii socjalizmu: t. 1: Własność i władza. O konieczności socjalizmu, t. 2: Droga do socjalizmu. O konieczności socjalizmu w Rosji, t. 3: Dynamika władzy. O strukturze i konieczności zaniku socjalizmu, Nakom, Poznań 1991. Zob. również wybrane omówienia, aplikacje i rozwinięcia: L. Nowak, Efekt kresowy w procesie historycznym, „Poznańskie Studia z Filozofii Humanistyki” t. 17, ss. 307-319; idem, O prognozie totalitaryzacji kapitalizmu. Próba oceny po dwudziestu latach, „Poznańskie Studia z Filozofii Humanistyki” t. 19: Ścieżki transformacji, red. K. Brzechczyn, Zysk i S-ka, Poznań 2003, ss. 361-400; K. Brzechczyn, Zapaść obywatelska i absorpcja elit. Próba poszerzenia teorii ewolucji społeczeństwa politycznego, „Poznańskie Studia z Filozofii Humanistyki” t. 17, ss. 399-404; idem, Odrębność historyczna Europy Środkowej. Studium metodologiczne, Wyd. Fundacji Humaniora, Poznań 1998; idem, Nie-Marksowski materializm historyczny Leszka Nowaka - stan obecny i perspektywy rozwojowe, w: J. Brzeziński, A. Klawiter, T.A.F. Kuipers, K. Łastowski, K. Paprzycka, P. Przybysz (red.), Odwaga filozofowania. Leszkowi Nowakowi w darze, Wyd. Fundacji Humaniora, Poznań 2002, ss. 303-325; idem, Upadek realnego socjalizmu $w$ Europie Wschodniej a załamanie się hiszpańskiego imperium kolonialnego w Ameryce Łacińskiej. Próba analizy porównawczej, „Poznańskie Studia z Filozofii Humanistyki” t. 19, ss. 37-80; idem, Upadek imperium socjalistycznego. Próba modelu, „Poznańskie Studia z Filozofii Humanistyki” t. 19, ss. 135-169; idem, O wielości linii rozwojowych w procesie historycznym. Próba interpretacji ewolucji społeczeństwa meksykańskiego, Wyd. Naukowe UAM, Poznań 2004; idem, O ewolucji solidarnościowej myśli społeczno-politycznej w latach 1980-1981, Wyd. Naukowe WNS UAM, Poznań 2013; idem, Jednostka a dwa ujęcia rewolucji politycznej w nie-Marksowskim materializmie historycznym, „Poznańskie Studia z Filozofii Humanistyki” t. 22: Jednostka w układzie społecznym. Próba teoretycznej konceptualizacji, red. K. Brzechczyn, M. Ciesielski, E. Karczyńska, Wyd. Naukowe WNS UAM, Poznań 2013, ss. 85-94; K. Paprzycka, M. Paprzycki, Jak dochodzi do wybuchu rewolucji?, „Poznańskie Studia z Filozofii Humanistyki” t. 22, ss. 77-84; E. Karczyńska, Struktura społeczna Imperium Osmańskiego. Próba analizy teoretycznej, „Poznańskie Studia z Filozofii Humanistyki” t. 22, ss. 273-290; M. Ciesielski, Świadomościowy wymiar rewolucji. Przypadek pętli i kontrpętli ideowej w Wielkiej Rewolucji Francuskiej, w: K. Brzechczyn, M. Nowak (red.), O rewolucji. Obrazy radykalnej zmiany społecznej, Wyd. Naukowe IF UAM, Poznań 2007, ss. 171-193; idem, Problem kumulacji podziałów klasowych we współczesnym kapitalizmie. Próba interpretacji teoretycznej, „Poznańskie Studia z Filozofii Humanistyki” t. 22, ss. 131-152. 
Każda z tych sfer zaś posiada analogiczną strukturę wewnętrzną: poziom materialny, instytucjonalny oraz świadomościowy ${ }^{5}$. Nie jest więc tak jak w koncepcji Marksowskiej, że poziom materialny charakterystyczny jest dla sfery gospodarczej, poziom instytucjonalny dla sfery politycznej, natomiast poziom świadomościowy występuje wyłącznie w sferze kulturowej. W koncepcji Nowaka poziom materialny występuje we wszystkich trzech sferach aktywności ludzkiej, podobnie jak dwa pozostałe poziomy - instytucjonalny i świadomościowy.

Teoria n-Mmh jako podstawowy poziom procesu społecznego przyjmuje poziom materialny. Dysponowanie środkami produkcji w gospodarce, środkami przymusu w polityce i środkami indoktrynacji w sferze kultury wyznacza trzy odrębne podziały klasowe. Istnieje więc sześć, odpowiednio parami, antagonistycznych wobec siebie klas społecznych: właściciele bezpośredni producenci, władcy - obywatele, kapłani - wierni. Odrzucony jest zatem Marksowski redukcjonizm ekonomiczny. W świetle n-Mmh zarówno polityka, jak i kultura, obok gospodarki, jawią się jako obszary autonomicznych podziałów klasowych, ze swoistą dynamiką rozwojową. Konflikty społeczne powodowane są podziałami klasowymi, w których dyspozycja materialnymi środkami umożliwia klasom uprzywilejowanym (właściciele, władcy, kapłani) realizację swoich interesów klasowych kosztem reszty społeczeństwa (bezpośredni producenci, obywatele, wierni). I tak, właścicielom na maksymalizowanie zysku kosztem bezpośrednich producentów (co pociąga za sobą wzrost alienacji pracy, czyli powiększenie obszaru niezaspokojenia potrzeb), władcom na powiększanie regulacji władczej kosztem autonomii obywateli (co pociąga za sobą wzrost alienacji obywatelskiej, czyli zmniejszenie autonomicznych więzi obywatelskich i zastąpienie ich zetatyzowanymi więzami zapośredniczonymi przez klasę władców), kapłanom zaś na pogłębianie indoktrynacji ideowej kosztem autonomii światopoglądowej wiernych (co pociąga za sobą wzrost alienacji duchowej wiernych, czyli zwiększenie u nich obszaru zdogmatyzowanych przekonań narzuconych przez klasę kapłańską).

Natężenie konfliktu klasowego w określonej sferze społecznej uzależnione jest od poziomu alienacji. Do jej konceptualizacji L. Nowak sformułował oryginalne ujęcie antropologiczne - tzw. nie-Ewangeliczny model człowieka ${ }^{6}$, który obok typowych działań w sytuacji „normalnej”

${ }^{5}$ Por. L. Nowak, O konieczności socjalizmu i konieczności jego zaniku, „Przyjaciel Nauk"1-2/1985-86, s. 105.

${ }^{6}$ Systematyczny wykład nie-Ewangelicznego modelu człowieka można znaleźć w: L. Nowak, Władza. Próba teorii idealizacyjnej, In Plus, Warszawa 1988; idem, U podstaw 
poddających się opisowi w kategoriach racjonalności działania - wyróżnia działania kon trracj onalne w sytuacji „zniewolenia” oraz irracjonalne w sytuacji „zbieszenia”. Antropologia nie-Ewangelicznego modelu człowieka pozwala uzasadnić twierdzenia dotyczące zjawisk z poziomu makro. I tak, w gospodarce i polityce konflikt klasowy przybiera formę wystąpień rewolucyjnych przy średnich wartościach odpowiednio alienacji pracy i alienacji obywatelskiej, kiedy to ucisk klas nieposiadających nie jest ani zbyt niski, bo wówczas jest nieodczuwalny i nie mobilizuje do protestów, ani zbyt wysoki, bo wtedy paraliżuje i uniemożliwia organizację wystąpień rewolucyjnych. Inaczej w przypadku konfliktu klas duchowych w kulturze: tu niski poziom alienacji duchowej oraz bardzo wysoki powoduje zaburzenia rewolucyjne - w pierwszym przypadku niezaspokojenie potrzeb posiadania systemu przekonań usensawniającego życie jednostki jest niezadowalający i wywołuje bunt duchowy, w drugim przypadku zbyt mała przestrzeń autonomii duchowej również powoduje niezadowolenie i sprzeciw wobec klasy kapłańskiej.

Wyróżnienie trzech autonomicznych podziałów klasowych stało się punktem wyjścia dalszej konceptualizacji teorii. Z jednej strony, ujęcie autonomicznych wobec siebie trzech interesów społecznych: pomnażanie zysku, wzrost regulacji politycznej oraz powiększanie panowania duchowego pozwala na skonceptualizowanie typologii społeczeństw (część typologizująca teorii). Z drugiej strony, w oparciu o metodologię idealizacji i konkretyzacji ${ }^{7}$

teorii socjalizmu, t. 3. Zob. również rozwinięcia, aplikacje i krytykę w: idem, Człowiek i ludzie, czyli ile utopii społecznej daje się wyprowadzić na obecnym etapie konkretyzacji nie-Marksowskiego materializmu historycznego, w: idem, Polska droga od socjalizmu. Pisma polityczne 1980-1989, wybór i oprac. K. Brzechczyn, IPN, Poznań 2011 [1985], ss. 569-580; idem, Gombrowicz: Człowiek wobec ludzi, Prószyński i S-ka, Warszawa 2000; K. Brzechczyn, Odrębność historyczna Europy Środkowej...; R. Egiert, Pewne wzmocnienie racjonalistycznego modelu człowieka, „Poznańskie Studia z Filozofii Humanistyki” t. 22, ss. 45-66; M. Paprzycki, Nie-Ewangeliczny model człowieka. Próba wyjaśnienia psychoanalitycznego, „Poznańskie Studia z Filozofii Humanistyki” t. 22, ss. 67-76; M. Ciesielski, Zagadnienie ograniczeń racjonalnego modelu działań ludzkich. Próba ujęcia działania nawykowo-racjonalnego, Wyd. Poznańskie, Poznań 2012; idem, Nie-Ewangeliczny model człowieka. O antropologii Leszka Nowaka, „Studia z Filozofii Polskiej” 8/2013, ss. 55-71; idem, Leszek Nowak's Non-Christian Model of Man and the Interdisciplinarity of the Humanities, „Studia Europaea Gnesnensia” 7/2013, ss. 87-111.

${ }^{7}$ Idealizacyjna teoria nauki, zakładana w konceptualizacji n-Mmh, została systematycznie opracowana przez L. Nowaka i środowisko poznańskiej szkoły metodologicznej; wykład teorii można znaleźć w: L. Nowak, Wstęp do idealizacyjnej teorii nauki, PWN, Warszawa 1977. 
ukazane są zależności rozwojowe oraz mechanizmy procesu społecznego poszczególnych typów społeczeństw (część nomotetyczna teorii).

Poprzestając na takim, siłą rzeczy, wstępnym przybliżeniu n-Mmh, możemy przejść do sklasyfikowania omawianej teorii w świetle przedstawionych we Wstępie paradygmatów.

N-Mmh można określić jako teorię materialistyczną, antagonistyczną oraz holistyczno-indywidualistyczną. W omawianej teorii jako czynnik główny procesów rozwojowych uznaje się materialne środki społecznego oddziaływania (produkcji, przymusu i indoktrynacji) oraz nierówny dostęp do dysponowania nimi, rodzący podstawę antagonizmu społecznego (trzy podziały klasowe). Modelowanie zjawisk, jakie ma miejsce w n-Mmh oparte na rozstrzygnięciach metodologii idealizacji i konkretyzacji - wprost wskazuje na materialistyczne oraz antagonistyczny ujęcie świata społecznego. W podstawowych modelach (ekonomicznym, politycznym oraz ekonomiczno-politycznym) idealizująco pominięte są czynniki związane ze sferą świadomości społecznej (ideologie i utopie), a obraz rozwoju społecznego zawiera wyłącznie wielkości materialistyczne: środki materialne, nierówny do nich dostęp oraz walkę klas spowodowaną poziomem zaspokojenia odpowiednich potrzeb mas społecznych. Idee społeczne, normatywne wizje świata społecznego itp., które są zarazem źródłem konsensusu społecznego, zostają uwzględnione w modelach pochodnych jako czynniki uboczne, korygujące tylko obraz podstawowego trendu rozwojowego.

Jeśli chodzi o holistyczno-indywidualistyczny charakter n-Mmh, to wyraża się on w modelowaniu zjawisk makrorozwojowych (dynamika walki klas, przejścia międzyformacyjne) przy wyraźnym uwzględnieniu antropologii nie-Ewangelicznego modelu człowieka, dzięki któremu uzasadnia się na poziomie mikro dynamikę zjawisk makro. Są to m.in.: wystąpienie zjawiska rewolucji przy średnim poziomie niezaspokojenia potrzeb, zjawisko wyciszenia nastrojów rewolucyjnych przy wysokim niezaspokojeniu, zjawisko tzw. rewolucji drugiego stopnia jako efekt aktywności jednostkowej postawy osobliwej: rewolucjonisty.

Można zatem powiedzieć, że w świetle przyjętych podziałów paradygmatycznych teoria n-Mmh ma dwojaki charakter. Ze względu na rozróżnienie materializm - idealizm oraz antagonizm - solidaryzm jest ona ujęciem „czystym” - opowiada się po jednej ze stron opozycji (materializm i antagonizm). Natomiast jeśli chodzi o podział holizm - indywidualizm, to teoria ta jest ujęciem „mieszanym” - uwzględnia obydwa poziomy wyjaśniania, co można odczytać jako ich swoistą integrację. 


\section{Założenia ograniczające integracyjny charakter n-Mmh}

W świetle stawianego w naukach społecznych postulatu dotyczącego przezwyciężania jednostronności ujęć teoretycznych na rzecz podejść integrujących $(P I)$, łączących opozycyjne paradygmaty, warto zastanowić się nad modyfikacją wybranych założeń teorii n-Mmh, tak by uczynić z niej ujęcie integrujące nie tylko opozycję holizm - indywidualizm, lecz również materializm/idealizm oraz antagonizm - solidaryzm.

Wskażę tu dwa założenia leżące u podstaw teorii n-Mmh, które poddane odpowiedniej korekcie pozwoliłyby z niej uczynić ujęcie integrujące wszystkie trzy opozycje. Założenia, o których mowa, to:

(1) typikalny uniwersalizm (materialistyczny) procesu społecznego,

(2) antagonistyczne ujęcie bytu społecznego.

\section{Od typikalnego uniwersalizmu (materialistycznego) do typikalnej cykliczności (materialistyczno-idealistycznej) procesu społecznego}

$\mathrm{N}-\mathrm{Mmh}$ jest teorią, która zakłada materialistyczne pojmowanie procesu społecznego. Można powiedzieć, że w stosunku do materializmu marksowskiego jest to ujęcie radykalne, bowiem poziom materialny - związany z dysponowaniem materialnymi środkami społecznymi i generowanym przez to podziałem klasowym - wskazany jest nie tylko w obszarze życia gospodarczego, jak czynił Marks, lecz także w polityce i kulturze.

Społeczeństwo w perspektywie n-Mmh przechodzi w swym rozwoju przez określone formacje społeczne za sprawą oddziaływania czynników materialnych - konfliktu klasowego wywołanego niezaspokojonymi potrzebami mas społecznych. A zatem istniejąca w danym czasie określona praktyka społeczna wkracza w obszar zaburzeń, których rozwiązanie następuje na gruncie nowej praktyki społecznej, do której adaptacyjnie dostosowuje się świadomość społeczna; tak właśnie, adaptacyjnie, rozumiana jest teza „byt społeczny określa świadomość społeczną”». Można to zilustrować w następujący sposób.

${ }^{8}$ Adaptacyjny charakter zależności świadomości od praktyki społecznej został opracowany przez L. Nowaka w ramach oryginalnej interpretacji materializmu historycznego Marksa. Następnie zaś twierdzenia adaptacyjne zostały wykorzystane - po odpowiednim uogólnieniu - w ramach nowej już teorii n-Mmh. Na temat adaptacyjnej interpretacji materializmu historycznego zob. m.in. L. Nowak, Teoria formacji społeczno-ekonomicznej jako 


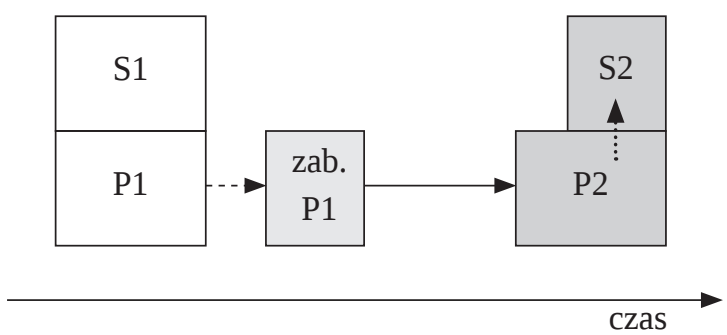

Rys. 1. Materialistyczna wizja rozwoju społecznego

Oznaczenia: $P 1, P 2$ - praktyka społeczna z, odpowiednio, wcześniejsza i późniejsza; $S 1$ i $S 2$ świadomość społeczna występująca w czasie trwania, odpowiednio, $P 1$ i $P 2$; zob. $P 1$ - szeroko rozumiane zaburzenia $P 1$, uniemożliwiające jej dalsze trwanie; strzałka przerywana - przejście $P 1$ w stan zaburzeń; strzałka ciągła - przyczynowe wyłonienie się i upowszechnienie $P 2$; strzałka kropkowana - upowszechnienie się $S 2$, adaptacyjnie uwarunkowanej przez P2.

W powyższy schemat wpisuje się ogólna wizja rozwoju społecznego zawarta w n-Mmh. Jest to wyraźnie widoczne w modelach opisujących rozwój obszaru gospodarczego, gdzie zaburzenia dotychczas istniejącej formy gospodarowania, wywołane wysokim poziomem alienacji pracy (zbyt niskim wynagrodzeniem bezpośrednich producentów w stosunku do ich potrzeb), prowadzi do pojawienia się nowej formy gospodarowania, pozwalającej obniżyć alienację pracy, do której następnie - ze zbioru istniejących form świadomości społecznej - adaptacyjnie dostosowuje się świadomość, która racjonalizuje nową formę gospodarowania.

Zauważmy, że przeciwnie rzecz ujęta jest na gruncie idealizmu historycznego, który stoi na stanowisku, że to świadomość społeczna (wierzenia religijne, ideologie polityczne itp.) określa byt społeczny. Graficznie można to zilustrować jak na rys. 2 .

Pod taki schemat podpada koncepcja powstania kapitalizmu Maxa Webera $^{9}$. Mające miejsce w XV i XVI wieku w Europie Zachodniej zmiany religijne, polegające na rozwoju doktryny chrześcijańskiej skutkującym powstaniem protestantyzmu, miały doprowadzić, zdaniem Webera, do

teoria adaptacyjna, „Poznańskie Studia z Filozofii Nauki” t. 3: Założenia materializmu historycznego, red. L. Nowak, PWN, Warszawa - Poznań 1978, ss. 59-75; idem, Adaptacyjna interpretacja materializmu historycznego: przegląd. Przyczynek do polskiego marksizmu analitycznego, w: Marksizm, liberalizm, próby wyjścia..., ss. 29-69; K. Łastowski, Teoria rozwoju gatunków a teoria ruchu formacji społeczno-ekonomicznej, „Poznańskie Studia z Filozofii Nauki” t. 3, ss. 113-155.

${ }^{9}$ M. Weber, Etyka protestancka a duch kapitalizmu, Test, Lublin 1994. 


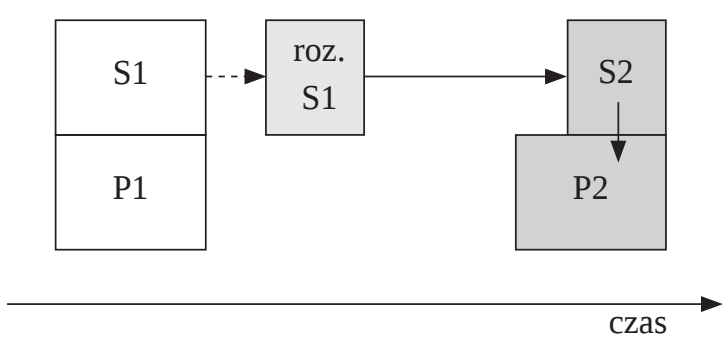

Rys. 2. Idealistyczna wizja rozwoju społecznego

Oznaczenia: $P 1, P 2, S 1$ i $S 2$ - analogicznie jak w rys. 1; roz. $S 1$ - ogólnie rozumiany rozwój $S 1$, prowadzący do pojawienia się $S 2$; strzałka przerywana - przejście $S 1$ w stan rozwoju; strzałka ciągła długa - przyczynowe wyłonienie się $S 2$ w wyniku rozwoju $S 1$; strzałka ciągła krótka - przyczynowe pojawienie się $P 2$ w wyniku upowszechnienia $S 2$.

wyłonienia się nowej, kapitalistycznej praktyki gospodarczej polegającej na ograniczeniu konsumpcji i maksymalizacji zysku.

Zamierzając wyjść naprzeciw sformułowanemu wyżej postulatowi integracji paradygmatów społecznych $(P I)$, należałoby przezwyciężyć wyraźnie widoczną na przedstawionych dwóch schematach jednostronność ujęć materialistycznego oraz idealistycznego. Integracja taka polega na docenieniu zarówno świadomości społecznej, jak i materialnie pojmowanej praktyki społecznej jako głównych, równorzędnych czynników kształtujących rozwój społeczny. Tyle tylko, że natężenie ich wpływu zmienia się w czasie, dzięki czemu możliwe jest równoczesne utrzymanie tezy: „byt kształtuje świadomość” oraz tezy: „świadomość kształtuje byt”.

Nie wchodząc w szczegóły, które nie doczekały się jeszcze systematycznej konceptualizacji, można uznać, że integracja materializmu i idealizmu historycznego polega na wyróżnieniu w rozwoju społecznym etapów różniących się między sobą czynnikami, które zasadniczo determinują proces społeczny: na pewnym etapie są to czynniki materialne (ogólnie ujmowane zaburzenia praktyki społecznej wpływają na upowszechnienie się nowej świadomości społecznej), natomiast na kolejnym etapie są to czynniki idealistyczne (upowszechniona świadomość społeczna wpływa na pojawienie się nowej praktyki społecznej). Omawianą ideę zmienności czynników głównych rozwoju społecznego ilustruje kolejny schemat.

Rozwój społeczny zatem - według powyższego schematu - kształtowany jest naprzemiennym wpływem czynników głównych w sekwencji: materialistyczne - idealistyczne - materialistyczne - idealistyczne itd. 


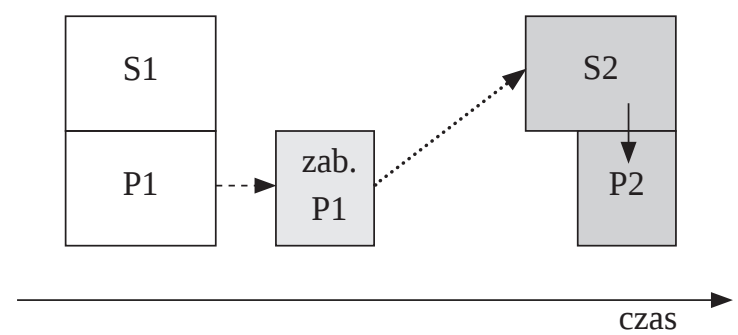

Rys. 3. Materialistyczno-idealistyczna wizja rozwoju społecznego

Oznaczenia: $P 1, P 2, S 1$ i $S 2$, zab. $P 1$ - analogicznie jak w rys. 1 ; strzałka przerywana - przejście $P 1$ w stan zaburzeń; strzałka kropkowana - upowszechnienie się $S 2$, adaptacyjnie uwarunkowanej przez zaburzenia $P 1$; strzałka ciągła - przyczynowe wyłonienie się $P 2$ w wyniku upowszechnienia $S 2$.

Innymi słowy, w świetle rozróżnienia koncepcji na metafizyczne i dialektyczne (te pierwsze zakładają stałość czynników istotnych, wpływających na badane zjawisko, te drugie wprowadzają zmienność w tym aspekcie ${ }^{10}$ ), można powiedzieć, że n-Mmh jest ujęciem dialektycznym na poziomie kategorii czynników (zakłada ich zmienność, jednakże w obrębie jednego typu materialnego), a zarazem ujęciem metafizycznym na poziomie typikalnym (zakłada stałość typu materialnego głównych determinant rozwoju społecznego). W przeciwieństwie do tego powiemy, że koncepcja zmierzająca do integracji materializmu oraz idealizmu historycznego powinna być ujęciem typikalnie dialektycznym, zawierającym zmienność w obrębie czynników głównych ze względu na ich materialistyczny/idealistyczny charakter.

Aby wprowadzić wspomniane ujęcie typikalnie dialektyczne, czyli zakładające naprzemienną zmianę typów czynników głównych: materialistyczne/idealistyczne, należy zmodyfikować jedno z założeń ontologicznych przyjmowanych na gruncie n-Mmh. W świetle ontologii kategorialnej ${ }^{11}$, na której oparty jest n-Mmh, mówi się o tzw. transformacji czynników wpływających na dane zjawisko, która polega na zmianie jego struktury

${ }^{10}$ Na temat rozróżnienia ujęć na metafizyczne i dialektyczne zob. L. Nowak, $U$ podstaw dialektyki marksowskiej. Próba interpretacji kategorialnej, PWN, Warszawa 1977; idem, Koncepcja historii w kategorialnej interpretacji dialektyki, „Poznańskie Studia z Filozofii Nauki” t. 2: Założenia dialektyki, red. L. Nowak, PWN, Warszawa - Poznań 1977, ss. 73-104.

${ }^{11} \mathrm{Na}$ temat ontologii kategorialnej, oryginalnego ujęcia ontologii i epistemologii opracowanego przez L. Nowaka zob. Wykłady z filozofii marksistowskiej, t. 1: Dialektyka, Wyd. Naukowe UAM, Poznań 1976; t. 2: Ontologia i epistemologia, Wyd. Naukowe UAM, Poznań 1978; idem, U podstaw dialektyki... 
esencjalnej w obrębie czynników głównych. Otóż, ciągi transformacji wraz z innymi możliwymi przekształceniami struktury esencjalnej to historia kategorialna danego zjawiska. Spośród różnych jej odmian warto przedstawić trzy zasadnicze:

- historia uniwersalna - w ciągu przekształceń danej kategorii przedmiotowej mamy do czynienia z jedną i tą samą strukturą esencjalną (przekształcenia przyjmują postać zdegenerowaną);

- historia kierunkowa - w ciągu przekształceń danej kategorii przedmiotowej jej struktury esencjalne są różne;

- historia odwracalna - w ciągu przekształceń danej kategorii przedmiotowej niektóre jej struktury esencjalne powtarzają się, w szczególności mogą powtarzać się cyklicznie ${ }^{12}$.

N-Mmh ujmuje proces społeczny jako historię kategorialnie kierunkową ${ }^{13}$ - zakłada się taką zmienność struktury esencjalnej rozwoju społecznego, w której konfiguracja czynników głównych i ubocznych nie powtarza się na poszczególnych etapach rozwoju.

Rozróżnienie na historię uniwersalną, kierunkową i odwracalną przeprowadzane jest na poziomie kategorii przedmiotowej - poszczególnych czynników istotnych. W kontekście rozważań nad próbą integracji materializmu i idealizmu historycznego, należy wyjść ponad poziom kategorialny i ująć także typikalny poziom ontologiczny, na którym mówi się nie o konkretnych czynnikach, lecz o typach czynników. A więc analogicznie do historii uniwersalnej, kierunkowej i odwracalnej na poziomie kategorialnym można wyróżnić historię typikalnie uniwersalną, kierunkową i odwracalną, czyli historię typów czynników. Zdefiniuję je następująco:

- historia typikalnie uniwersalna - w ciągu przekształceń danej kategorii przedmiotowej typy czynników głównych w jej strukturach esencjalnych są takie same;

- historia typikalnie kierunkowa - w ciągu przekształceń danej kategorii przedmiotowej typy czynników głównych w jej strukturach esencjalnych są różne;

- historia typikalnie odwracalna - w ciągu przekształceń danej kategorii przedmiotowej typy czynników głównych w jej strukturach esencjalnych powtarzają się, w szczególności mogą powtarzać się cyklicznie.

12 L. Nowak, U podstaw dialektyki..., ss. 146-180.

${ }^{13}$ Warto także zauważyć, że prace Krzysztofa Brzechczyna rozwijające n-Mmh wskazują, że teoria ta dopuszcza wielość linii rozwojowych społeczeństw ludzkich, co można zinterpretować, że kierunkowa historia kategorialna rozwoju społecznego, jaką zakłada n-Mmh, zawiera rozszczepienia kategorialne. Zob. K. Brzechczyn, O wielości linii rozwojowych $w$ procesie historycznym. 
Mając zdefiniowane pojęcia poszczególnych historii typikalnych ${ }^{14}$, można spróbować określić, do której z nich należy teoria n-Mmh. Z uwagi na przyjmowany w niej repertuar czynników głównych, które są wyłącznie typu materialnego, n-Mmh zawiera typikalnie uniwersalną wizję historii rozwoju społeczeństw klasowych. Struktury esencjalne poszczególnych formacji społeczno-ekonomicznych - od niewolniczej, poprzez feudalną, kapitalistyczną, do socjalistycznej - jako czynniki główne zawierają determinanty materialne: ekonomiczne (model niewolnictwa i feudalizmu) oraz polityczno-ekonomiczne (model kapitalizmu i socjalizmu).

Natomiast teoria integrująca materializm i idealizm w sposób zarysowany w niniejszych rozważaniach nie zawiera typikalnie uniwersalnej wizji historii rozwoju społecznego, lecz zakłada historię typikalnie cykliczną (odwracalną). Poszczególne czynniki główne nie powtarzają się na kolejnych etapach rozwoju historycznego (mamy tu historię kategorialnie kierunkową), jednakże typy czynników głównych już tak: jest to powtarzalność cykliczna - naprzemienne oddziaływanie determinant materialistycznych oraz idealistycznych jako czynników głównych procesu historycznego.

A zatem w n-Mmh powinno się zastąpić założenie historii typikalnie uniwersalnej materialistycznej założeniem historii typikalnie cyklicznej materialistyczno-idealistycznej, co nie wyklucza kategorialnej kierunkowości, ale pozwala ją uchwycić w szerszych ramach cyklicznie zmiennych typów ontologicznych.

\section{Od antagonizmu społecznego do ujęcia ekologiczno-społecznego}

Postulowana ogólna teoria społeczna - przypomnijmy słowa L. Nowaka miałaby być ani antagonistyczna, ani solidarystyczna. Tymczasem n-Mmh jest teorią antagonistyczną - podział klasowy, i to nie tylko w obszarze gospodarczym, lecz także niezależnie w polityce i kulturze, jest głównym motorem dynamiki społecznej. W przeciwieństwie do tego ujęcia solidarystyczne opisują byt społeczny konsensualnie, najczęściej upatrując źródła ładu i dynamiki społecznej we wspólnotowych wartościach czy w postępie technologicznym. W ujęciach tych rozwój społeczny przejawia się przede wszystkim w wymiarze cywilizacyjnym, z którego korzyści czerpią wszyscy członkowie, niezależnie od przynależności do grupy społecznej.

${ }^{14}$ Pominę w tym miejscu analizę związków między poszczególnymi historiami z poziomu kategorialnego i typikalnego - jest to zagadnienie wymagające osobnego opracowania. 
Zauważmy, że zwykle ujęcia zarówno antagonistyczne, jak i solidarystyczne opierają się na założeniu, iż źródłem dynamiki społecznej są czynniki natury społecznej: walka klas (ogólniej: grup posiadających sprzeczne interesy) w pierwszym przypadku bądź rozwój świadomości społecznej, wiedzy naukowej i umiejętności technologicznych w drugim.

Tymczasem wydaje się, że jest to założenie ograniczające, bo pomija przypadek, gdy źródłem ładu i rozwoju społecznego jest interakcja między społecznością a otoczeniem niespołecznym (przyrodniczym, naturalnym). Jest to zapewne zasadniczy czynnik dla społeczności stacjonarnych, plemiennych, żyjących niejako „blisko natury” i dlatego od niej uzależnionych. Dynamika rozwoju społeczności stacjonarnych u zarania ludzkiej historii jest kształtowana przede wszystkim okolicznościami zewnętrznymi (szeroko rozumianymi warunkami przyrodniczymi), do których bytowanie społeczne musi się dostosować. Z braku bowiem wystarczających środków technicznych, wiedzy i umiejętności nie jest możliwe skuteczne wpływanie i przekształcanie przyrodniczych okoliczności bytowania.

Ujęcie konceptualizujące w punkcie wyjścia obraz, w którym przesądza się o wyłącznie społecznym charakterze czynników wpływających na rozwój społeczny, nie jest w stanie uchwycić długiej historii dawnych społeczności stacjonarnych. W n-Mmh tak właśnie jest: teoria już w punkcie wyjścia zakłada społeczny motor procesu historycznego w postaci walki klas i tym samym przyjmuje jednostronną perspektywę antagonistyczną, zawężając tym samym swój zakres odniesienia do społeczeństw wyłącznie klasowych $^{15}$.

${ }^{15}$ Na gruncie n-Mmh dokonywane są próby uwzględnienia elementów solidarystycznych (cywilizacyjnych); cztery najważniejsze z nich zawierają artykuły: G. Tomczak, Modele zaburzonego rozwoju społecznego: katastrofa i załamanie, „Poznańskie Studia z Filozofii Nauki” t. 9: Klasy - światopogląd - idealizacja, red. P. Buczkowski, A. Klawiter. PWN, Warszawa Poznań 1985, ss. 47-70; L. Nowak, Efekt kresowy w procesie historycznym, w: Marksizm, liberalizm, próby wyjścia..., ss. 307-319; M. Buchowski, Społeczeństwo pre-momentowe. Próba uzupełnienia nie-Marksowskiego materializmu historycznego, „Poznańskie Studia z Filozofii Humanistyki” t. 19, ss. 295-316; K. Brzechczyn, Wymiar cywilizacyjny nie-Marksowskiego materializmu historycznego. Rekapitulacja dotychczasowych ujęć i próba rozwinięcia, „Studia z Filozofii Polskiej” 8/2013, ss. 43-53. Choć wskazane wyżej uzupełnienia niewątpliwie wzbogacają n-Mmh o aspekt cywilizacyjny, wprowadzając elementy solidarystyczne do obrazu zjawisk społecznych, jednak trudno te próby uznać za przekształcenie n-Mmh w teorię integrującą paradygmat antagonistyczny i solidarystyczny. Są to bowiem uzupełnienia cząstkowe i wskazujące ewentualnie kierunki dalszej i bardziej systematycznej reinterpretacji podstawowych antagonistycznych twierdzeń n-Mmh. 
Wyraźnie o tym pisze Andrzej Falkiewicz w książce powstałej na podstawie korespondencji prowadzonej z twórcą n-Mmh, L. Nowakiem:

Żadnego z trzech momentów [własności, władzy, wiary - M.C.] nie można idealizować osobno od początku - ponieważ nie ma jeszcze tych momentów. W punkcie - nazwijmy go - Alfa jest trój-ale-jeszcze-jedność. [...] Jest siła, która zdobywa środki do życia, jest „posiadanie” potomstwa i jest pierwsze pytanie zdziwionych ludzi, po co są, skąd się wzięli ${ }^{16}$.

Widzimy tu nie tylko sugestię, aby w punkcie wyjścia potraktować społeczeństwo jako całość niezróżnicowaną ze względu na wewnętrzną strukturę obszarów (podział na politykę, gospodarkę i kulturę), ale także jako całość pozbawioną grup o antagonistycznych interesach klasowych i wspólnie zabiegającą o swój byt. Dobitniej o tym cytowany autor pisze dalej:

Jest punkt Alfa: trój-ale-jeszcze-jedności. I dopiero kiedy nastąpią pierwsze dokonania (odpowiedzi, zaszłości) typu cywilizacyjnego, ergo ponadklasowego, ergo solidarystycznego; i kiedy poszczególne momenty drogą specjalizacji, podziału pracy etc. zaczną się rozdzielać; i kiedy w każdym z momentów zaczną wyodrębniać się układy cywilizacyjne i klasowe, [...] otóż dopiero wtedy można mówić o społeczeństwie klasowym, czyli po prostu o społeczeństwie (bo przedtem jest pierwotna wspólnota, a „potem”, w tym naszym marzonym i nieprawdopodobnym „potem” - ludzka komunia) ${ }^{17}$.

Przyjmowana w n-Mmh w punkcie wyjścia klasowa wizja społeczeństwa uniemożliwia (a przynajmniej zasadniczo utrudnia) konceptualizację społeczeństw nieklasowych o charakterze wspólnotowym, solidarystycznym ${ }^{18}$. Jest to po części związane, jak można przypuszczać, z rozstrzygnięciem metateoretycznym świadomie dokonanym przez L. Nowaka już na wstępie prac konceptualizacyjnych, a dotyczącym problemu dwuznaczności materializmu historycznego: czy motorem dziejów ludzkich jest rozwój sił wytwórczych wchodzących w sprzeczność z istniejącymi stosunkami produkcji, czy też sprzeczność interesów i walka klas właścicieli oraz bezpośrednich producentów? Problem dwuznaczności historiozofii marksowskiej jest przez L. Nowaka rozwiązany na korzyść tej ostatniej: to nie rozwój sił wytwórczych, postęp technologiczny wymuszający zmiany ogólnospołeczne, lecz walka klas (ekonomicznych, politycznych i duchowych) jest

${ }^{16}$ A. Falkiewicz, Jeden i liczba mnoga, Kret, Wrocław 1989, s. 11.

17 Ibidem, s. 12.

${ }^{18}$ Odnotować tu należy próbę wzbogacenia języka n-Mmh o kategorię społeczeństw stacjonarnych: M. Buchowski, Społeczeństwo pre-momentowe... 
motorem dziejów ludzkich. To zaś sprawia, że solidarystyczne, związane z wymiarem cywilizacyjnym, aspekty rozwoju społecznego wymykają się konceptualnemu ujęciu.

Należy podkreślić, że klasowa wizja społeczeństwa zawarta w n-Mmh przyjmuje jako istotne czynniki rozwoju społecznego wyłącznie wielkości natury społecznej i całkowicie abstrahuje od uwarunkowań rozwojowych na linii przyroda - społeczeństwo, które niejednokrotnie mają ważny wpływ na kształt i poziom życia społeczeństw ludzkich (wskazać tu można nie tylko prehistorię ludzkich społeczeństw, ale także gwałtowne zmiany ekologiczne, epidemie czy narastający problem wyczerpywania się zasobów naturalnych).

Wydaje się zatem, że teoria zmierzająca do integracji opozycji solidaryzm - antagonizm w punkcie wyjścia powinna konceptualizować źródło dynamiki procesu społecznego w kategoriach na tyle ogólnych, by nie przesądzać od razu, czy źródło to ma charakter społeczny, czy przyrodniczy. W zarysowanym szkicowo ujęciu integrującym materializm - idealizm (rys. 3) swoisty motor dynamiki społecznej kryje się pod kategorią „zaburzeń praktyki społecznej” i ta właśnie kategoria powinna być w punkcie wyjścia konceptualizacji ujęta na tyle ogólnie, by nie przesądzać o jej przyrodniczym lub społecznym charakterze, lecz tylko ująć jej funkcję polegającą na inicjowaniu zmian w obrębie świadomości społecznej. Dopiero na dalszym etapie konceptualizacji teorii powinno mieć miejsce dokładniejsze i wariancyjne określenie natury tych zaburzeń: „,zewnętrzne”, ekologiczne (wymuszające perspektywę solidarystyczną - ujęcie społeczeństwa jako całości bytującej w określonym otoczeniu przyrodniczym), czy „wewnętrzne”, społeczne (skłaniającą do perspektywy antagonistycznej - ujęcie społeczeństwa jako struktury złożonej z klas/grup społecznych o przeciwstawnych interesach).

\section{Podsumowanie}

Odpowiednia modyfikacja omówionych wyżej założeń ontologicznych i teoretycznych n-Mmh pozwoliłaby przekształcić tę teorię w ujęcie integrujące opozycyjne paradygmaty nauk społecznych. W obecnym kształcie n-Mmh jest koncepcją integrującą holizm oraz indywidualizm - nie-Ewangeliczny model człowieka jest założeniem antropologicznym, które pozwala wyjaśnić niektóre zjawiska makrorozwojowe w perspektywie działań jednostek opisanych w modelu nie-Ewangelicznym; jeśli chodzi o opozycje materializm - idealizm oraz antagonizm - solidaryzm, to n-Mmh wpisuje się w materialistyczne i antagonistyczne widzenie świata społecznego. Aby przekształcić omawianą teorię w ujęcie integrujące również te dwie opozycje, należałoby: 
- zastąpić typikalny uniwersalizm materialistyczny założeniem typikalnej cykliczności materialistyczno-idealistycznej procesu społecznego (czyli wprowadzić naprzemienne występowanie determinant materialnych oraz świadomościowych w roli czynników głównych procesu społecznego);

- zastąpić antagonistyczne (klasowe) widzenie świata społecznego założeniem ekologiczno-społecznym, w którym czynniki kształtujące rozwój społeczny nie tylko są natury społeczno-antagonistycznej, lecz również uwzględnić uwarunkowania ekologiczne (swoiście zewnętrzne wobec społeczeństwa jako całości) pozwalające ująć proces społeczny w kategoriach cywilizacyjnych (solidarystycznych).

Proponowana w niniejszym tekście modyfikacja n-Mmh pozwoliłaby na konceptualizację uogólnionej teorii rozwoju społecznego, spełniającej - wyraźnie stawiany przez współczesnych badaczy - postulat budowy ujęć teoretycznych, które przezwyciężają opozycje dotychczasowych paradygmatów nauk społecznych. Kwestią odrębną, wykraczającą poza zakres tego artykułu, pozostaje moc eksplanacyjna i prewidystyczna takiej integracyjnej teorii, powstałej na bazie twierdzeń teoretycznych nie-Marksowskiego materializmu historycznego.

\section{Literatura}

Brzechczyn K., Zapaść obywatelska i absorpcja elit. Próba poszerzenia teorii ewolucji społeczeństwa politycznego, „Poznańskie Studia z Filozofii Humanistyki” t. 17: Marksizm, liberalizm, próby wyjścia, red. L. Nowak, P. Przybysz, Poznań 1997.

Brzechczyn K., Odrębność historyczna Europy Środkowej. Studium metodologiczne, Poznań 1998.

Brzechczyn K., Nie-Marksowski materializm historyczny Leszka Nowaka - stan obecny i perspektywy rozwojowe, w: J. Brzeziński, A. Klawiter, T.A.F. Kuipers, K. Łastowski, K. Paprzycka, P. Przybysz (red.), Odwaga filozofowania. Leszkowi Nowakowi w darze, Poznań 2002.

Brzechczyn K., Upadek imperium socjalistycznego. Próba modelu, „Poznańskie Studia z Filozofii Humanistyki” t. 19: Ścieżki transformacji, red. K. Brzechczyn, Poznań 2003.

Brzechczyn K., Upadek realnego socjalizmu w Europie Wschodniej a załamanie się hiszpańskiego imperium kolonialnego w Ameryce Łacińskiej. Próba analizy porównawczej, „Poznańskie Studia z Filozofii Humanistyki” t. 19: Ścieżki transformacji, red. K. Brzechczyn, Poznań 2003.

Brzechczyn K., O wielości linii rozwojowych w procesie historycznym. Próba interpretacji ewolucji społeczeństwa meksykańskiego, Poznań 2004.

Brzechczyn K., O ewolucji solidarnościowej myśli społeczno-politycznej w latach 19801981, Wyd. Naukowe WNS UAM, Poznań 2013.

Brzechczyn K., Jednostka a dwa ujęcia rewolucji politycznej w nie-Marksowskim materializmie historycznym, „Poznańskie Studia z Filozofii Humanistyki” t. 22: Jednostka 
w układzie społecznym. Próba teoretycznej konceptualizacji, red. K. Brzechczyn, M. Ciesielski, E. Karczyńska, Wyd. Naukowe WNS UAM, Poznań 2013.

Brzechczyn K., Wymiar cywilizacyjny nie-Marksowskiego materializmu historycznego. Rekapitulacja dotychczasowych ujęć i próba rozwinięcia, „Studia z Filozofii Polskiej” 8/2013.

Buchowski M., Społeczeństwo premomentowe. Próba uzupełnienia nie-Marksowskiego materializmu historycznego, „Poznańskie Studia z Filozofii Humanistyki” t. 19: Ścieżki transformacji, red. K. Brzechczyn, Poznań 2003.

Ciesielski M., Świadomościowy wymiar rewolucji. Przypadek pętli i kontrpętli ideowej w Wielkiej Rewolucji Francuskiej, w: K. Brzechczyn, M. Nowak (red.), O rewolucji. Obrazy radykalnej zmiany społecznej, Poznań 2007.

Ciesielski M., Zagadnienie ograniczeń racjonalnego modelu działań ludzkich. Próba ujęcia działania nawykowo-racjonalnego, Poznań 2012.

Ciesielski M., Leszek Nowak's Non-Christian Model of Man and the Interdisciplinarity of the Humanities, „Studia Europaea Gnesnensia” 7/2013.

Ciesielski M., Nie-Ewangeliczny model człowieka. O antropologii Leszka Nowaka, „Studia z Filozofii Polskiej” 8/2013.

Ciesielski M., Problem kumulacji podziałów klasowych we współczesnym kapitalizmie. Próba interpretacji teoretycznej, „Poznańskie Studia z Filozofii Humanistyki” t. 22: Jednostka w układzie społecznym. Próba teoretycznej konceptualizacji, red. K. Brzechczyn, M. Ciesielski, E. Karczyńska, Poznań 2013.

Egiert R., Pewne wzmocnienie racjonalistycznego modelu człowieka, „Poznańskie Studia z Filozofii Humanistyki” t. 22: Jednostka w układzie społecznym. Próba teoretycznej konceptualizacji, red. K. Brzechczyn, M. Ciesielski, E. Karczyńska, Poznań 2013.

Falkiewicz A., Jeden i liczba mnoga, Wrocław 1989.

Giddens A., Stanowienie społeczeństwa. Zarys teorii strukturacji, Poznań 2003.

Karczyńska E., Struktura społeczna Imperium Osmańskiego. Próba analizy teoretycznej, „Poznańskie Studia z Filozofii Humanistyki” t. 22: Jednostka w układzie społecznym. Próba teoretycznej konceptualizacji, red. K. Brzechczyn, M. Ciesielski, E. Karczyńska, Poznań 2013.

Łastowski K., Teoria rozwoju gatunków a teoria ruchu formacji społeczno-ekonomicznej, „Poznańskie Studia z Filozofii Nauki” t. 3: Założenia materializmu historycznego, red. L. Nowak, Warszawa - Poznań 1978.

Nowaka L., Wykłady z filozofii marksistowskiej, t. 1: Dialektyka, Poznań 1976.

Nowak L., Koncepcja historii w kategorialnej interpretacji dialektyki, „Poznańskie Studia z Filozofii Nauki” t. 2: Założenia dialektyki, red. L. Nowak, Warszawa - Poznań 1977.

Nowak L., U podstaw dialektyki marksowskiej. Próba interpretacji kategorialnej, Warszawa 1977.

Nowak L., Wstęp do idealizacyjnej teorii nauki, Warszawa 1977.

Nowak L., Teoria formacji społeczno-ekonomicznej jako teoria adaptacyjna, „Poznańskie Studia z Filozofii Nauki” t. 3: Założenia materializmu historycznego, red. L. Nowak, Warszawa - Poznań 1978.

Nowaka L., Wykłady z filozofii marksistowskiej, t. 2: Ontologia i epistemologia, Poznań 1978.

Nowak L., O konieczności socjalizmu i konieczności jego zaniku, „Przyjaciel Nauk” 1-2/1985-86.

Nowak L., Władza. Próba teorii idealizacyjnej, Warszawa 1988. 
Nowak L., U podstaw teorii socjalizmu: t. 1: Własność i władza. O konieczności socjalizmu, t. 2: Droga do socjalizmu. O konieczności socjalizmu w Rosji, t. 3: Dynamika władzy. O strukturze i konieczności zaniku socjalizmu, Poznań 1991.

Nowak L., Adaptacyjna interpretacja materializmu historycznego: przegląd. Przyczynek do polskiego marksizmu analitycznego, „Poznańskie Studia z Filozofii Humanistyki” t. 17: Marksizm, liberalizm, próby wyjścia, red. L. Nowak, P. Przybysz, Poznań 1997.

Nowak L., Efekt kresowy w procesie historycznym, „Poznańskie Studia z Filozofii Humanistyki” t. 17: Marksizm, liberalizm, próby wyjścia, red. L. Nowak, P. Przybysz, Poznań 1997.

Nowak L., Marksizm versus liberalizm: pewien paradoks, „Poznańskie Studia z Filozofii Humanistyki” t. 17: Marksizm, liberalizm, próby wyjścia, red. L. Nowak, P. Przybysz, Poznań 1997.

Nowak L., Gombrowicz: Człowiek wobec ludzi, Warszawa 2000.

Nowak L., O prognozie totalitaryzacji kapitalizmu. Próba oceny po dwudziestu latach, „Poznańskie Studia z Filozofii Humanistyki” t. 19: Ścieżki transformacji, red. K. Brzechczyn, Poznań 2003.

Nowak L., Człowiek i ludzie, czyli ile utopii społecznej daje się wyprowadzić na obecnym etapie konkretyzacji nie-Marksowskiego materializmu historycznego, w: L. Nowak, Polska droga od socjalizmu. Pisma polityczne 1980-1989, wybór i oprac. K. Brzechczyn, Poznań 2011 [1985].

Paprzycka K., M. Paprzycki, Jak dochodzi do wybuchu rewolucji?, „Poznańskie Studia z Filozofii Humanistyki” t. 22: Jednostka w układzie społecznym. Próba teoretycznej konceptualizacji, red. K. Brzechczyn, M. Ciesielski, E. Karczyńska, Poznań 2013.

Paprzycki M., Nie-Ewangeliczny model człowieka. Próba wyjaśnienia psychoanalitycznego, „Poznańskie Studia z Filozofii Humanistyki” t. 22: Jednostka w układzie społecznym. Próba teoretycznej konceptualizacji, red. K. Brzechczyn, M. Ciesielski, E. Karczyńska, Poznań 2013.

Tomczak G., Modele zaburzonego rozwoju społecznego: katastrofa i załamanie, „Poznańskie Studia z Filozofii Nauki” t. 9: Klasy - światopogląd - idealizacja, red. P. Buczkowski, A. Klawiter, Warszawa-Poznań 1985.

Weber M., Etyka protestancka a duch kapitalizmu, Lublin 1994. 
